\title{
PERLINDUNGAN KORBAN MELALUI KOMPENSASI DALAM PERADILAN PIDANA ANAK
}

\author{
Hafrida $^{a}$, Helmi $^{\mathrm{b}}$
}

\begin{abstract}
ABSTRAK
Artikel ini bertujuan untuk menganalisis konsep perlindungan korban melalui kompensasi dalam peradilan pidana anak sebagai wujud tanggungjawab negara. Peradilan Pidana Anak di Indonesia melalui UndangUndang Nomor 11 Tahun 2012 mengedepankan penyelesaian perkara anak melalui keadilan restoratif yang memberikan perlindungan yang seimbang antara perlindungan pelaku anak melalui diversi dan perlindungan korban tindak pidana anak. Diversi yang memberikan perlindungan yang seimbang antara pelaku dan korban ini merupakan pembaharuan dalam hukum pidana anak yang berkeadilan untuk semua pihak (Victim-offender oriented). Keterlibatan korban/keluarganya dan pelaku/keluarganya sangat menentukan berhasil atau tidaknya diversi dalam penyelesaian perkara anak. Posisi pelaku/keluarganya dan korban/keluarganya adalah sejajar. Kepentingan kedua belah pihak harus sama dan seimbang. Perlindungan korban melalui kompensasi merupakan wujud tanggungjawab negara terhadap warga negara yang menjadi korban tindak pidana. Kondisi empirik menurut data Badilum MA menunjukan rendahnya keberhasilan diversi (4\%), kegagalan diversi ini penyebab utamanya adalah tidak tercapainya kesepakatan ganti kerugian karena kesepakatan diversi hanya diserahkan sepenuhnya pada kesepakatan pelaku dan korban. Disinilah menunjukan bahwa negara abai terhadap perlindungan korban, seharusnya ketika negara melindungi kepentingan pelaku anak melalui diversi maka seharusnya negara juga menjamin perlindungan korbannya melalui kompensasi, sehingga ke depan diharapkan tingkat keberhasilan diversi akan semakin baik.
\end{abstract}

Kata kunci: kompensasi; korban tindak pidana; peradilan pidana anak; perlindungan korban.

\section{ABSTRACT}

This article aimed to analyze the concept of victim protection through compensation in juvenile criminal justice as a form of state responsibility. Juvenile Criminal Court in Indonesia through Law Number 11 of 2012 prioritizes the settlement of juvenile cases through restorative justice providing balanced protection between juvenile offenders through diversion and protection for victims of juvenile crimes through reform of juvenile criminal law that is just for all parties (victim-offender oriented). The involvement of the victim and his family and the perpetrator and his family will greatly determine the success or failure of diversion in solving juvenile cases. The position of the perpetrator and his family and the victim and his family are equal. The interests of both parties should be equal and balanced. Protection of victims through compensation is a form of state responsibility towards citizens who are victims of criminal acts. The empirical condition according to Badilum's data showed the low success of diversion (4\%). The failure of this diversion is the main cause of the failure to reach an agreement for compensation because the diversion agreement is only left to the agreement of the perpetrator and victim. This showed that the state was ignorant of victim protection. When the state protects the interests of juvenile through diversion, the state should also guarantee the protection of the victims through compensation. Hence, the success rate of diversion will hopefully be better in the future.

Keywords: compensation; juvenile criminal court; victims of crime; victim protection.

\footnotetext{
a Fakultas Hukum Universitas Jambi, Jalan Jambi-Ma. Bulian KM 15 Mendalo Indah Jambi, email: hafrida_hukum@unja.ac.id.

b Fakultas Hukum Universitas Jambi, Jalan Jambi-Ma. Bulian KM 15 Mendalo Indah Jambi, email: helmi@unja.ac.id.
} 


\section{PENDAHULUAN}

Prinsip keadilan pada pemidanaan di Indonesia awalnya berdasarkan pada prinsip keadilan retributif di mana pemidanaan ditujukan sebagai sarana pembalasan atas perbuatan jahat yang telah dilakukan. Pelaku perbuatan pidana merupakan pihak yang bersalah atas perbuatan yang terjadi dan harus mendapat balasan atas perbuatannya tersebut dan pembalasan berupa sanksi pidana merupakan konsekwensi atas perbuatan pidana yang telah dilakukan. Dalam perkembangan selanjutnya prinsip keadilan retributif ini diperluas maknanya dimana pemidanaan bukan hanya semata-mata sebagai pembalasan tetapi ada tujuan lain yang ingin dicapai yaitu pembinaan narapidana (rehabilitatif).

Kedua prinsip keadilan tersebut, baik prinsip keadilan retributif maupun prinsip keadilan rehabilitatif masih bertumpu dan fokus pada kepentingan pelaku tindak pidana dan pada kepentingan/perlindungan pelaku semata. Pada prinsip keadilan rehabilitatif menekankan pada pembinaan pelaku tindak pidana. Rehabilitasi pelaku tindak pidana di lembaga pemasyarakatan merupakan fokus utama. Pada kedua prinsip ini belum memberikan perhatian yang layak bagi kepentingan/perlindungan korban sementara perlindungan korban dalam proses penyelesaian perkara pidana seharusnya merupakan fokus utama. Sebagai reaksi atas pendekatan dalam penyelesaian perkara pidana yang hanya terfokus pada kepentingan pelaku tindak pidana semata maka kemudian mulai mendapat perhatian tentang pendekatan penyelesaian perkara melalui prinsip keadilan restoratif.

Keadilan restoratif adalah merupakan pendekatan dalam Penyelesaian suatu perkara pidana melalui keterlibatan banyak pihak seperti pihak pelaku/keluarganya, korban/keluarganya dan kelompok masyarakat terkait. Dengan demikian keadilan restoratif memiliki tujuan baik yang ingin dicapai bagi korban tindak pidana, bukan semata-mata bertumpu pada kebaikan dan kepentingan pelaku tindak pidana semata karena keadilan restoratif bersumber dari akar nilai yang diusung oleh nilai-nilai tradisional dalam masyarakat tradisional. Dasar pemikiran Keadilan restoratif inilah yang kemudian menjadi hal yangmendasar dalam perubahan peraturan perundang-undangan peradilan pidana anak melalui Undang-Undang Nomor 11 Tahun 2012.

Undang-Undang Nomor 11 Tahun 2012 tentang Sistem Peradilan Pidana Anak (UU SPPA) mengatur mengenai "Diversi". Diversi adalah pengalihan penyelesaian perkara Anak dari proses peradilan pidana ke proses di luar peradilan pidana dan pelaksanaan diversi ini harus lebih mengedepankan "keadilan restorative" sebagaimana disebutkan penyelesaian perkara anak sejak dimulainya pemeriksaan pada proses penyidikan wajib dilaksanakan dengan mengedepankan keadilan restoratif. Keadilan restoratif merupakan suatu pendekatan dalam penyelesaian suatu perkara pidana dengan melibatkan pihak-pihak terkait yaitu pelaku dan keluarga pelaku, korban dan 
Perlindungan Korban Melalui Kompensasi Dalam Peradilan Pidana Anak

keluarga korban, dan pihak lainnya untuk mendapatkan formulasi penyelesaian perkara dengan berlandaskan pada keuntungan bagi kedua belah pihak.

Bentuk penyelesaian perkara anak melalui pendekatan keadilan restoratif ini dilaksanakan melalui "diversi". Dalam proses penyelesaian melalui mekanisme diversi ini dilaksanakan melalui suatu musyawarah para pihak yang disebut dengan "musyawarah diversi". Sehingga melalui diversi akan terjadi pengalihan proses pada sistem penyelesaian perkara anak yang kaku dan menimbulkan trauma bagi anak sebagai pelaku dan memberikan korban dan keluarga korban akan terlindungi dengan mendapatkan ganti kerugian. Mediasi melalui musyawarah dalam diversi dilakukan untuk mencapai keadilan restoratif.

Data Empirik pada Sistem Data Base Pemasyarakatan (SDBP) pada akhir november 2019 menunjukan saat ini terdapat 1.822 anak pidana yang tersebar pada 33 (tiga puluh tiga) Lembaga Pembinaan Khusus Anak (LPKA) di seluruh Indonesia. Kondisi ini menunjukan bahwa sekalipun telah berlaku UU No. 11 Tahun 2012 tentang Sistem Peradilan Pidana Anak, secara kuantitas masih banyak anak-anak pelaku tindak pidana yang berakhir di Lembaga Pemasyarakatan Anak. Banyaknya anak pelaku tindak pidana yang berahir di Lembaga Pemasyarakatan menunjukan bahwa tingkat keberhasilan diversi masih rendah.

Keadilan restoratif merupakan reaksi atas prinsip keadilan retributif dalam pemidanaan. Teori keadilan tentang pemidanaan yang paling tradisional adalah teori keadilan retributif, teori keadilan rehabilitatif dan kemudian mulai bergeser kepada teori keadilan yang lebih modern yaitu teori keadilan restoratif. Keadilan restoratif ini merupakan alternatif dalam penyelesaian perkara pidana karena bertujuan mengurangi beban sistem peradilan pidana melalui penyelesaian di luar sistem peradilan dengan berbagai bentuk penyelesaian yang lebih konstruktif dan menguntungkan kedua belah pihak. Tujuan keadilan restoratif ini sebagaimana dalam Handbook on Restorative Justice Programmes: Restorative justice programmes can be used to reduce the burden on the criminal justice system, to divert cases out of the system and to provide the system with a range of constructive sanctions.

Keadilan restoratif inilah yang menjadi nyawa dari Undang-Undang Sistem Peradilan Anak saat ini. Keadilan restoratif ini merupakan upaya perbaikan atau koreksi terhadap konsep keadilan pada sistem peradilan pidana sebelumnya dengan memperluas keterlibatan pihak-pihak yang dalam proses penyelesaian perkara melalui sistem peradilan pidana saat ini belum mendapatkan keadilan yang seharusnya. Sebagaimana dalam Rufinus, Umbreit menyebutkan bahwa "Restorative Justice is a victim-centered response to crime that allows the victim, the offender, their families, and representatives of the community to address the harm caused by the crime". ("tanggapan terhadap tindak pidana yang berpusat pada korban yang mengizinkan korban, pelaku tindak pidana, keluarga- 
keluarga mereka, dan para perwakilan dari masyarakat untuk menangani kerusakan dan kerugian yang diakibatkan oleh tindak pidana". Selanjutnya Howard Zehr mengatakan bahwa "crime is a violation of people and relationship. It creates obligations to make things right. Justice involve the victim, the offender, and the community in a search for solutions which promote repair, reconciliation, and reassurance". Menurut pandangan Zehr ini kejahatan dipandang sebagai pelanggara terhadap warga masyarakat dan hubungannya antar anggota masyarakat. Pelanggaran ini memunculkan kewajiban bagi pihak terkait untuk menemukan penyelesaian. Penyelesaian dimaksud merupakan penyelesaian yang memberikan solusi, perbaikan, rekonsiliasi dan jaminan bagi keadilan tidak hanya untuk pelaku tetapi juga korban dan masyarakat.

Permasalahan terletak pada kondisi dimana prinsip keadilan restoratif yang mengutamakan perlindungan kepentingan korban belum terjabarkan dengan baik. rendahnya keberhasilan diversi di Indonesia menunjukan bahwa kesedpakan kesepakatan ganti kerugian antara korban dan pelakut indak pidana anak tidak tercapai. Tidak tercapainya keberhasilan diversi ini penyebabnya adalah ganti kerugian untuk korban digantungkan sepenuhnya pada kemampuan pelaku/keluarganya. Disinilah letak abainya negara dalam perlindungan korban, seharusnya negara bertanggungjawab atas korban dalam tindak pidana anak melalui kompensasi. Terjaminnya ganti kerugian korban tindak pidana dalam perkara anak melalui kompensasi akan memberikan peluang bagi keberhasilan diversi.

Kedudukan korban dalam sistem peradilan pidana Indonesia termasuk dalam peradilan pidana anak dewasa ini masih terabaikan karena hukum pidana Indonesia masih berorientasi pada kepentingan pelaku (Offenfer Oriented) sementara jika kita simak laporan simposium pertama viktimologi menyebutkan: Victimology may be defined as the scientific study of victims. Special attention, however, should be devoted to the problems of victims of crime, the primary concern of this. (Viktimologi dapat didefinisikan sebagai studi ilmiah tentang korban, perhatian khusus bagaimanapun harus ditujukan untuk masalah-masalah korban kejahatan, merupakan perhatian utama).

Keterpaduan antara perlindungan anak sebagai pelaku tindak pidana dan perlindungan terhadap korban dalam perkara anak merupakan syarat penting dalam mewujudkan peradilan pidana anak terpadu sehingga diharapkan dapat merumuskan konsep keadilan restoratif yang lebih memiliki nilai keadilan berimbang korban dan pelaku tindak pidana sehingga diharapkan akan dapat mewujudkan diversi yang efektif dan mengembalikan fungsi hukum pidana sebagai ultimum remidium. 
Perlindungan Korban Melalui Kompensasi Dalam Peradilan Pidana Anak

\section{METODE PENELITIAN}

Artikel ini merupakan suatu penelitian hukum doktrinal sehingga artikel ini ditulis melalui penelusuran literatur hukum dan peratura perundang-undangan terkait dengan obyek tulisan ini. Penelusuran literatur hukum dalam kerangka melakukan penelusuran asas hukum, konsep hukum dan/atau norma hukum. Hasil penelusuran ini baik penelusuran bahan pustaka hukum maupun peraturan perundang-undangan terkait akan dijadikan sebagai dasar dalam pembahasan dan kesimpulan melalui suatu pendekatan berpikir yang kritis dan rasional.

\section{PEMBAHASAN}

\section{Perlindungan Anak dalam Peradilan Pidana Anak}

Anak sebagai pelaku tindak pidana sebelum berlakunya Undang-undang No. 11 Tahun 2012 tentang SPPA masih menempatkan pidana penjara menjadi sanksi utama dan yang paling sering diterapkan dan pada ahirnya anak sebagai pelaku tindak pidana berahir di Lembaga Pemasyarakatan. Selain itu dalam undang-undang yang lama tidak mengenal mekanisme perlindungan korban melalui proses mediasi. Beberapa dampak negatif yang dapat ditimbulkan dari penempatan anak di Lembaga Pemasyarakatan Anak baik akibat langsung maupun tidak langsung yaitu: (1) perkembangan anak secara psikologis terganggu karena dipengaruhi oleh kondisi sosial institusional lembaga; (2) perilaku sosial anak akan terganggu karena pergaulan/interaksi antara anak dan anak lainnya atau dengan terpidana lain jika di tempatkan di Lembaga Pemasyarakatan; (3) dampak fisik dan biologis menempatkan anak pada posisi rentan menjadi korban kekerasan, baik kekerasan fifik maupun kekerasan seksual.

Dalam Pasal 1 butir 6 Undang-undang SPPA disebutkan Diversi adalah pengalihan penyelesaian perkara anak dari proses peradilan pidana ke proses di luar peradilan pidana, dan dalam Pasal 7 ayat (1) disebutkan tentang kewajiban untuk mengupayakan diversi pada setiap tahapan pemeriksaaan, mulai tahapan penyidikan, penuntutan dan tahapan pemeriksaan dipersidangan. Kewajiban diversi merupakan proses yang harus diupayakan pada setiap tahapan proses pemeriksaan mulai tahapan penyidikan, penuntutan, dan pemeriksaan pada tahapan pengadilan. Pelaksanaan diversi dalam peradilan peradilan anak ini adalah untuk mencapai kesepakatan antara korban dan anak, menghindarkan anak dari pemidanaan yang berupa perampasan kemerdekaan, mendorong masyarakat untuk berpartisiasi selain itu mewujudkan tanggungjawab pada anak. Filosofi yang mendasari pelaksanaan diversi dalam mencapai tujuan diversi ini menunjukan adanya pergeseran filosofi dalam penyelesaian perkara anak yang semula adalah retributive justic kemudian bergeser ke rehabilitative dan saat ini berdasarkan undangundang ini landasan filosofi penyelesaian perkara anak bergeser ke filosofi restorative justice. 
Keterlibatan korban dan keluarganya dan pelaku dan keluarganya sangat menentukan berhasil atau tidaknya diversi dalam penyelesaian perkara anak. Posisi pelaku dan keluarganya dan korban serta keluarganya adalah sejajar. Kepentingan kedua belah pihak harus sama dan seimbang. Jika kepentingan salah satu pihak saja yang diutamakan maka dapat dipahami jika kesepakatan diversi akan sulit terwujud. Hal ini disebutkan dalam Pasal 6 ayat (1) bahwa "Proses Diversi wajib memperhatikan:

a. kepentingan korban;

b. kesejahteraan dan tanggung jawab anak;

c. penghindaran stigma negatif;

d. penghindaran pembalasan;

e. keharmonisan masyarakat; dan

f. kepatutan, kesusilaan, dan ketertiban umum

Menurut ketentuan tersebut maka "Kepentingan korban" merupakan hal yang sangat strategis sehingga harus sungguh-sungguh diperhatikan dalam keberhasilan diversi. Pasal 7 ayat (1) disebutkan tentang kewajiban untuk mengupayakan diversi pada setiap tahapan pemeriksaaan, mulai tahapan penyidikan, penuntutan dan tahapan pemeriksaan dipersidangan. Dengan demikian diversi merupakan kewajiban yang harus diupayakan pada setiap tahapan pemeriksaan mulai tahapan penyidikan, penuntutan dan pemeriksaan di sidang pengadilan. Filosofi yang mendasari pelaksanaan diversi dalam mencapai tujuan diversi ini menunjukan adanya pergeseran filosofi dalam penyelesaian perkara anak yang semula adalah retributive justice kemudian bergeser ke rehabilitative dan saat ini berdasarkan undang-undang ini landasan filosofi penyelesaian perkara anak bergeser ke filosofi restorative justice.

Keseimbangan perlindungan pelaku (anak) dan korban dalam perkara anak inilah yang akan menjadi pusat analisis penulis dalam mewujudkan Pengadilan anak terpadu. Hukum pidana melalui peraturan perundang-undangan seharusnya mampu melindungi hak asasi manusia baik secara baik dan seimbang antara hak asasi pelaku maupun hak asasi korban serta hukum pidana mampu melindungi kepentingan-kepentingan semua pihak dengan seimbang demi terwujudnya tujuan dari sistem peradilan pidana. Dalam Kongres PBB ke-XI Tahun 2005 tentang Pencegahan Kejahatan dan Peradilan Pidana pada butir 32, untuk mempromosikan kepentingan korban dan rehabilitasi pelaku tindak pidana, kami mengakui pentingnya mengembangkan lebih lanjut kebijakan, prosedur dan program peradilan restoratif, termasuk alternatif untuk penuntutan, dengan demikian menghindari kemungkinan efek yang merugikan dari penjara, membantu mengurangi beban pengadilan pidana dan mempromosikan penggabungan pendekatan keadilan restoratif ke dalam sistem peradilan pidana. 
Perlindungan Korban Melalui Kompensasi Dalam Peradilan Pidana Anak

Sejalan dengan berbagai dokumen tersebut, maka tujuan diversi di Indonesia diatur dalam peraturan perundang-undangan yang mengatur tentang tujuan diversi yaitu, mencapai perdamaian antara korban dan anak, penyelesaian perkara anak di luar pengadilan, menghindarkan anak dari proses pemeriksaan di sidang pengadilan, pemidanaan bukanlah merupakan pembalasan, menciptakan ketertiban masyarakat, serta menanamkan rasa tanggungjawab kepada anak. Melihat pada tujuan diversi maka Proses peradilan pidana anak melalui diversi menurut undang-undang ini masih mengutamakan kepentingan anak pelaku tindak pidana, kepentingan korban belum sungguhsungguh terlindungi. Sementara menurut Pasal 6 ayat (1) Undang-undang ini menyebutkan bahwa proses diversi harus memperhatikan kepentingan korban. Hal ini menunjukkan bahwa perlindungan korban tindak pidana belum terjabarkan dengan baik dalam pasal-pasal pada undang-undang ini. Keberpihakan Negara masih terlihat keberpihakannya yaitu masih berpihak pada pelaku tindak pidana dalam hal ini pelaku tindak pidana anak melalui pengaturan hak-hak anak pelaku tindak pidana dan selalu mengutakan kepentingan terbaik bagi anak. Tidak demikian halnya dengan perlindungan korban pada perkara pidana yang pelakunya anak. Keberpihakan negara terhadap korban menurut peneliti merupakan unsur penentu dalam keberhasilan diversi.

Tujuan sistem peradilan pidana menurut Philip. P. Purpura dalam Didik Sunaryo menyatakan bahwa "sistem peradilan pidana (criminal justice system) merupakan suatu sistem yang terdiri dari Kepolisian, Kejaksaan, Pengadilan, dan Lembaga Pemasyarakatan yang bertujuan untuk melindungi dan menjaga ketertiban masyarakat, mengendalikan kejahatan, melakukan penangkapan, dan penahanan terhadap pelaku kejahatan, memberikan batasan bersalah atau tidaknya seseorang, memidana pelaku yang bersalah dan melalui komponen sistem secara keseluruhan dapat memberikan perlindungan hukum terhadap hak-hak terdakwa". Menurut Muladi sistem peradilan pidana sesuai dengan makna dan ruang lingkup sistem dapat bersifat phisik dalam arti sinkronisasi struktural (structural syncronization) dalam arti keselarasan mekanisme administrasi peradilan pidana, dapat pula bersifat substansial (substancial syncronization) dalam kaitannya dengan hukum positif yang berlaku, dan dapat pula bersifat kultural (cultural syncronization) dalam arti menghayati pandangan, sikap, dan falsafah yang secara menyeluruh mendasari jalannya sistem peradilan pidana.

Penyelesaian perkara pidana dengan melibatkan banyak pihak dan mendapatkan penyelesaian yang menguntungkan semua pihak baik pihak pelaku maupun korban tindak pidana masih merupakan hal yang baru. Salah satu bentuk proses penyelesaian perkara yang memberi ruang bagi pihak korban untuk mendapatkan perlindungan salah satunya adalah melalui pendekatan keadilan restoratif. Achilles and Zehr dalam Margarita Zernova menyebutkan Restorative justice is presented as a way of responding to crime which would place victims at its centre and include as many opportunities for participation, voice, and choices for victims as possible. [KeadilanRestoratif 
merupakan cara untuk merespon kejahatan dengan penempatan korban sebagai pusat dan termasuk banyak peluang dan pilihan yang mungkin bagi para korban].

Penyelesaian perkara dengan pelakunya anak dilaksanakan dengan mempertemukan pelaku dan korban tindak pidana. Menurut Willian Bakker disebut dengan hukum pidana mediasi. Tujuan hukum pidana mediasi ini adalah mendapatkan kesepakatan bersama antara korban dan pelaku dan ganti kerugian pada korban. Kesepakatan ini di mediatori oleh seorang mediator atau lebih baik yang berasal dari aparat penegak hukum, pihak pemerintah, pihak LSM ataupun dari tokoh masyarakat. Menurut peraturan perundang-undangan yang dimaksud mediasi adalah suatu bentuk lembaga musyawarah yang biasa dilaksanakan dalam ranah hukum umum, yang biasa digunakan dalam penyelesaian perkara perdata.

Berawal dari pemikiran keadilan bagi korban kejahatan inilah yang kemudian menjadi dasar dalam pemikiran keadilan restoratif. Peradilan pidana selama ini berorientasi pada pelaku tindak pidana dan perlindungan pelaku tindak pidana. Prinsip keadilan yang berorientasi pada pembalasan pada pelaku adalah prinsip keadilan retributif (retributive justice). Pada prinsip keadilan retributif ini memandang bekerjanya sistem peradilan pidana semata-mata hanya bertujuan untuk mencegah terjadinya kembali kejahatan tersebut dengan menjatuhkan pidana yang dimaksudkan untuk penjeraan. Sanksi pidana penjara yang dijatuhkan hanya berorientasi pada kejahatan yang terjadi dan pemberian sanksi pada pelaku kejahatan merupakan reaksi mutlak yang pantas diterapkan pada pelaku kejahatan. Sehingga keadila retributif tidak dapat mencapai tujuan mendasar dari pemidanaan yaitu keadilan yang seimbang antara keadilan pada pelaku dan keadilan pada korban.

Sebagai reaksi atas prinsip keadilan restoratif tersebut adalah prinsip keadilan restoratif. Dalam kerangka sistem peradilan pidana prinsip keadilan restoratif ini dapat dicapai melalui mediasi penal. Mediasi penal merupakan pendekatan dalam penyelesaian perkara yang merupakan pendekatan yang mengakar dari masyarakat dan mengakar dalam hukum adat yang dipraktekkan dalam penyelesaian konflik di Indonesia. Sehingga dapat dikatakan bahwa hukum adat merupakan akar dari prinsip keadilan restoratif. Berkenaan dengan hal ini sebagaimana dalam Eva Achjani Zulfa, Marc Levin menyebutkan bahwa pendekatan hukum adat yang dinilai usang, kuno dan tradisional kini disebut sebagai suatu pendekatan dalam penyelesaian perkara pidan yang progresif. Keadilan dalam restorative justice mengharuskan untuk adanya upaya pemulihan/mengembalikan kerugian atau akibat yang ditimbulkan oleh tindak pidana, dan pelaku dalam hal ini diberi kesempatan untuk dilibatkan dalam upaya pemulihan tersebut. Semua itu dalam rangka memelihara ketertiban masyarakat dan memelihara perdamaian yang adil. 
Perlindungan Korban Melalui Kompensasi Dalam Peradilan Pidana Anak

Sejalan dengan perkembangan dalam prinsip-prinsip keadilan yang mengalami perubahan mendasar dari keadilan retributif menuju keadilan restoratif ini juga sejalan dengan perkembangan dalam teori pemidanaan. Teori pemidanaan yang semula berdasarkan pada teori retribution atau teori pembalasan yang secara absolut diberikan pada pelaku tindak pidana sebagai upaya pembalasan yang kemudian diikuti dengan konsep restraint atau pengasingan yang diterapkan pada pelaku dengan maksud agar pelaku kejahatan dijauhkan atau diasingkan dari kehidupan masyarakat. Teori ini kemudian sesuai dengan perkembangan zaman berubah kearah konsep reformation atau rahabilitation. Konsep ini tetap berorientasi pada pelaku tindak pidana tetapi terhadap pelaku yang dijatuhi pidana penjara tidak sekedar diasingkan tetapi juga dalam pengasingannya tersebut pelaku tindak pidana dibina dan diperbaiki dan direhabilitasi agar dapat kembali menjadi orang yang baik dan dapat kembali kekehidupan masyarakat.

\section{Keseimbangan Perlindungan Pelaku Anak dan Korban Tindak Pidana dalam perkara anak (Victim- Offender Orientaion) menuju Integrated Juvenile Justice}

Dalam hal peradilan pidana anak, beberapa ahli hukum pidana anak, ahli psikologi anak dan ahli prilaku anak melihat bahwa pendekatan keadilan restoratif merupakan pendekatan yang tepat dalam sistemperadilan pidana anak dalam rangka penyelesaian perkara anak yang terlibat dalam suatu tindak pidana. Keadilan restoratif dalam perkara anak diharapkan tidak hanya memberika perlindungan pada pelaku tindak pidana anak tetapi juga diharapkan dapat memberikan rasa keadilan bagi korban.

Melalui pendekatan keadilan restoratif dalam penyelesaian perkara anak ini maka penyelesaian perkara pidananya dengan memulihkan secara bersama baik kerusakan yang ditimbulkan karena kejahatan maupun pertanggungjawaban pelaku. Perkara pidana harus dipandang sebagai suatu konflik dalam hubungan antar anggota masyarakat dalam hal ini sebagai korban dengan pelaku tindak pidana. Melalui mekanisme keadilan restoratif dengan partisipasi pihak-pihak yang terlibat untuk secara aktif dalam merumuskan bentuk penyelesaian yang saling menguntungkan ini maka akan memberikan kesempatan kepada korban untuk berperan dalam merumuskan bentuk penyelesaian yang dirasa adil bagi dirinya. Pendekatan keadilan restoratif ini memberikan keterlibatan penuh bagi korban dalam penyeesaian perkaranya, dimana peran korban selama ini masih tersisihkan.

Konsep keadilan restoratif juga dikemukakan oleh Umbreit, Restorative Justice is a "victimcentered response to crime that allows the victim, the offender, their families, and representatives of the community to address the harm caused by the crime". (Keadilan restorative adalah sebuah "tanggapan terhadap tindak pidana yang berpusat pada korban yang mengizinkan korban, pelaku 
tindak pidana, keluarga-keluarga mereka, dan para perwakilan dari masyarakat untuk menangani kerusakan dan kerugian yang diakibatkan oleh tindak pidana". Selanjutnya masih mengenai konsep keadilan restoratif dikemukan oleh Howard Zehr, Viewed through a restorative justice lens, "crime is a violation of people and relationship. It creates obligations to make things right. Justice involve the victim, the offender, and the community in a search for solutions which promote repair, reconciliation, and reassurance". Menurut pandangan Howard Zehr ini keadilan restoratif memandang kejahatan merupakan pelanggaran terhadap rakyat dan merusak nilai-nilai yang ada dalam masyarakat. Oleh sebab itu kejahatan menuntut suatu kewajiban bagi pelaku untuk membuat suatu penyelesaian. Penyelesaian yang berkeadilan dengan melibatkan kepentingan korban, pelaku dan kepentingan masyarakat yang kemudian secara bersama-sama mendapatkan solusi perbaikan, rekonsiliasi dan jaminan.

Karakteristik dari Keadilan restoratif dikemukakan oleh Muladi diantaranya titik perhatian pada pemecahan masalah tentang pertanggungjawaban dan kewajiban semata-mata ditujukan pada kepentingan masa depan; prinsip penyelesaian masalah berbasis pada negosiasi dan dialog; tujuan utama dari penyelesaian konflik adalah restitusi, rekonsiliasi dan restorasi; sebagai fasilitator adalah masyarakat; keadilan merupakan hubungan hak yang dinilai atas dasar hasil; peran korban mendapat perhatian utama pelaku tindak pidana didorong untuk bertanggungjawab dengan memberikan ganti kerugian pada korban.

Arif Gosita dan Angkasa menilai dengan tiadanya jaminan perlindungan hukum bagi korban dalam sistem peradilan pidana dapat menimbulkan viktimisasi bagi korban. Seharusnya tanggung jawab terhadap korban tindak pidana adalah tanggung jawab negara. Negara berkewajiban untuk menerapkan sanksi pidana kepada pelaku kejahatan dalam rangka untuk menjaga tertib hukum, dengan demikian dapat menghindarkan masyarakat untuk main hakim sendiri dan dengan penerapan sanksi tersebut diharapkan pelaku dapat diperbaiki. Keadilan yang diberikan negara dengan penerapan sanksi kepada pelaku dengan tujuan agar pelaku dapat diperbaiki dan kembali ke tenagh masyarakat seharusnya sama dan seimbang dengan keadilan yang seharusnya diterima oleh korban. Jika negara berperan dalam penegakan hukum bagi pelaku maka negara seharusnya juga bertanggungjawab bagi pemulihan kerugian korban terutama dalam peradilan pidana anak.

Tanggungjawab negara ini khususnya dalam konteks penegakan hukum mencakup aspek yang luas, baik aspek substansi, institusi, kultur dan sarana prasarana penegakan hukum. "Langkah ke arah itu adalah membenahi eksistensi, independensi, dan imparsialitas institusi utama penegakan hukum yaitu Kepolisian, Kejaksaan, dan Kehakiman agar ketiganya menjadi lokomotif penegakan hukum yang mencerminkan kuatnya moralitas kekuasaan hukum agar penegakan hukum mewujudkan kepastian, keadilan dan kemanfaatan sejalan dengan karakter negara hukum yang kita 
Perlindungan Korban Melalui Kompensasi Dalam Peradilan Pidana Anak

cita-citakan". Oleh sebab itu korban suatu tindak pidana seharusnya dilindungi oleh undang-undang, dalam formulasi suatu tindak pidana terdapat dua sisi yang saling berhubungan yaitu pelaku tindak pidana dan korban tindak pidana.

Keterpaduan sistem peradilan pidana merupakan keterpaduan gerak antara subsistem lembaga penegak hukum mulai dari Kepolisian, Kejaksaan, Pengadilan dan Lembaga Pemasyarakatan. Menurut Muladi tujuan sistem peradilan pidana terbagi atas tujuan jangka pendek, tujuan jangka menengah dan tujuan jangka panjang. Tujuan jangka pendek berupa sosialisasi, tujuan sistem peradilan pidana jangka menengah yaitu pencegahan kejahatan dan kesejahteraan sosial merupakan tujuan jangka panjang. Subsistem pada sistem peradilan pidana anak terdiri dari berbagai subsistem yang terkait dengan proses peradilan anak yaitu: Kepolisian, Kejaksaan, Pengadilan Anak, Lembaga Pembinaan Khusus Anak (LPKA) ditambah Balai Pemasyarakatan. Melalui sub sistem peradilan pidana anak ini diharapkan dapat mewujudkan tujuan peradilan anak yang dilaksanakan melalui musyawarah diversi yaitu kepentingan terbaik bagi anak.

Berdasarkan tujuan tersebut maka keberhasilan Peradilan anak diukur dari keberhasilan kesepakatan diversi antara korban (keluarganya) dan pelaku (keluarganya) selain itu Diversi menghindarkan anak pelaku tindak pidana dari proses formal peradilan pidana ke luar peradilan. Melalui diversi aparat penegak hukum untuk semua tingkatan proses wajib mengedepankan penyelesaian di luar peradilan pidana. Tetapi, diversi juga dapat dilakukan oleh masyarakat dengan cara mendamaikan kedua belah pihak: korban dan pelaku. Menurut Harkristuti Harkrisnowo, "pada dasarnya diversi bertujuan untuk mencegah anak masuk ke dalam sistem peradilan anak. Namun, diversi hanya dapat dilakukan dengan izin korban dan keluarga korban, serta kesediaan dari pelaku dan keluarganya". Diversi yang dilaksanakan melalui keadilan restoratif dengan mengedepankan kepentingan anak sebagai pelaku dan korban dalam tindak pidana anak menunjukkan bahwa keberhasilan peradilan pidana anak sangat bergantung dari izin korban dan keluarganya. Tanpa adanya persetujuan korban (keluarganya) maka proses diversi melalui keadilan restoratif tidak akan terwujud.

Prinsip Keadilan restoratif yang menjadi nyawa dari Undang-Undang Sistem Peradilan Anak ini merupakan upaya perbaikan atau koreksi terhadap konsep keadilan pada sistem peradilan pidana sebelumnya melalui keterlibatan pihak-pihak yang lebih luas yang selama ini belum memperoleh rasa keadilan. Diharapkan secara bersama-sama menentukan penyelesaian yang lebih adil dan memberi pengaruh yang baik bagi semua pihak. Bertitik tolak dari Undang-Undang Nomor 11 Tahun 2012 tentang Sistem Peradilan Pidana Anak terlihat bahwa undang-undang ini hanya mengedepankan perlindungan terhadap anak sebagai pelaku, sementara perlindungan terhadap 
korban terabaikan. Negara absen dalam memberikan perlindungan terhadap korban dalam perkara tersebut.

Kedudukan korban dalam sistem peradilan pidana Indonesia termasuk dalam peradilan pidana anak dewasa ini masih terabaikan karena hukum pidana Indonesia masih berorientasi pada kepentingan pelaku (Offenfer Oriented) sementara jika kita simak laporan simposium pertama viktimologi menyebutkan: Victimology may be defined as the scientific study of victims. Special attention, however, should be devoted to the problems of victims of crime, the primary concern of this. (Viktimologi dapat didefinisikan sebagai studi ilmiah tentang korban, perhatian khusus bagaimanapun harus ditujukan untuk masalah-masalah korban kejahatan, merupakan perhatian utama) Selanjutnya Shapland menuliskan korban sebagai unforgotten man (manusia yang terlupakan).

Dalam kerangka tanggung jawab negara terhadap korban tindak pidana dapat diwujudkan dengan pemberian kompensasi. Pengertian kompensasi dalam PP adalah bentuk ganti kerugian yang menjadi tanggungjawab negara yang dinerikan pada korban dikarenakan pelaku tidak mampu membayar ganti kerugian kepada korban. Selanjutnya pengertian restitusi dan kompensasi menurut Joe Hudson, "The concepts of restitution and compensation are Increasingly suggested as remedies to be made available through public social policy for crime victims to obtain reparation. While the terms, "restitution" and "compensation" are often used interchangeably, restitution will be defined here to refer to payments made by the offender to the victims of crime." Walaupun peraturan perundang-undangan telah mengatur tentang kewajiban negara untuk membayrkan ganti kerugian bagi korban tindak pidana dalam hal pelaku tidak mampu membayar ganti kerugian sebagaimana diatur tersebut tetapi dalam kenyataannnya kewajiban akan kompensasi ini belum terlaksana sebagaimana mestinya. Sementara di sisi lain korban tindak pidana menjadi faktor yang menentukan dalam mengungkapkan suatu tindak pidana. Tanpa peran serta yang baik dari korban dalam pengungkapan suatu perkara maka dapat dipastikan suatu perkara akan menjadi dark number of the crime.

Kondisi tidak terlaksananya kompensasi kewajiban pemerintah atas kompensasi disebabkan belum diaturnya dengan baik tentang kewajiban ini. Dalam Peraturan Pemerintah Republik Indonesia Nomor 44 Tahun 2008 pada Pasal 2 membatasi korban yang mendapatkan kompensasi hanya terbatas pada korban pelanggaran HAM dan korban terorisme. Absennya negara dalam memberikan perlindungan pada korban tindak pidana khususnya korban tindak pidana dalam perkara anak mengakibatnya rendahnya tingkat keberhasilan diversi. Salah satu faktor utama penyebab gagalnya diversi adalah tidak tercapainya kesepakatan ganti kerugian antara korban dan pelaku. Keberpihakan negara terhadap anak sebagai pelaku tindak pidana melalui Undang-Undang 
Perlindungan Korban Melalui Kompensasi Dalam Peradilan Pidana Anak

Nomor 11 Tahun 2012 terlihat dengan baik tetapi negara abai dalam memberikan perlindungan kepada korban. Hal ini mengakibatkan masih rendahnya tercapainya kesepakatan diversi di Indonesia. Perlindungan terhadap korban melalui keberpihakan negara dalam menjamin hak kompensasi terhadap korban dalam perkara anak akan memberikan dampak positif pada keberhasilan diversi ke depannya.

\section{Perlindungan Korban Dalam Perkara Anak Melalui Kompensasi Sebagai Upaya Meningkatkan} Keberhasilan Diversi

Konsep kompensasi tidak berarti negara mengambil alih tanggung jawab pelaku tetapi negara membayar hak gugat korban terhadap pelaku. Dalam konsep subrograsi dalam perkara perdata maka korban kehilangan hak gugatnya setelah negara memberikan kompensasi. Kebijakan hukum pidana tentang kompensasi berdasarkan pada konsep pemikiran bahwa kompensasi diposisikan sebagai suatu kewajiban negara dalam memberikan kompensasi kepada korban kejahatan sebagai wujud tanggungjawab negara atas korban tindak pidana. Perlindungan terhadap korban tindak pidana tidak hanya terhadap beberapa tindak pidana saja sebagaimana yang diatur dalam peraturan perundang-undangan seperti saat ini, tetapi juga perlu dipertimbangkan terhadap korban tindak pidana dalam perkara anak demi terwujudnya perlindungan yang seimbang antara pelaku tindak pidana anak dan korban tindak pidana dalam perkara anak. Pemberian perlindungan yang penuh kepada anak pelaku tindak pidana dengan tidak memproses perkaranya melalui proses peradilan harus diimbangi dengan pemberian perlindungan kepada korban dalam tindak pidana tersebut. Perlindungan kepada korban tindak pidana dalam perkara anak melalui kompensasi akan memberikan efek positif bagi terwujudnya perlindungan terhadap pelaku anak melalui keberhasilan kesepakatan diversi dan tidak memproses perkara anak tersebut ke dalam proses peradilan. Sebagimana Warren G Foote (State Compensation for Victims of Crime, 1992) pemberian kompensasi kepada korban bertujuan untuk memastikan adanya respon yang lebih efektif kepada korban dalam sitem peradilan pidana.

Tidak hanya di Indonesia dan Thailand, dibeberapa tempat di dunia telah dibentuk lembaga baik yang didanai pemerintah maupun swasta yang ditujukan untuk dukungan korban tidak hanya untuk ganti kerugian materiil tetapi juga dukungan untuk terapi, psiko patologi pasca trauma dan gangguan stress traumatis, termasuk pengobatan medis yang diperlukan. Survey di AS mengindikasikan bahwa para korban tindak pidana serius lebih mungkin melaporkan kebutuhan akan layanan dukungan korban daripada korban lainnya, Survei lain di Pennsylvania menunjukkan bahwa $64 \%$ korban kejahatan menggunakan layanan korban, dibandingkan dengan hanya $24 \%$ korban kejahatan tanpa kekerasan. Implikasinya ada dua: Pertama, pengguna layanan korban 
mungkin lebih cenderung menjadi korban kekerasan serius; dan kedua, evaluasi dukungan korban harus membedakan pengguna antara viktimisasi kekerasan dan non-kekerasan, karena kedua kelompok mungkin memiliki kebutuhan yang berbeda. Sebelum peninjauan temuan penelitian sebelumnya, pengantar fokus saat ini dari dukungan korban untuk korban langsung dan tidak langsung diberikan, memberikan alasan untuk pandangan subjektif korban dalam evaluasi dukungan korban.

Perlindungan yang seimbang atas korban dan pelaku dalam perkara anak akan berdampak pada terwujudnya Peradilan Pidana Anak Terpadu (Integrated Juvenile Justice) untuk itu diperlukan revisi Undang-Undang Sistem Peradilan Pidana Anak dan Undang-Undang Perlindungan Saksi dan Korban. Sehingga fungsi sistem peradilan pidana anak sebagai pengendali kejahatan, perlindungan terhadap pelaku anak juga perlindungan korban dalam berjalan serampak dan harmonis. Perlindungan hukum yang seimbang atas anak sebagai pelaku kejahatan dan korban tindak pidana melalui revisi Undang-Undang penting dilakukan secara adil dalam kerangka mencapai nilai keadilan yang ingin dicapai melalui perlindungan hukum yang dijabarkan dalam hukum tertulis maka hukum tertulis tersebut harus mampu mencerminkan nilai-nilai keadilan yang hidup dalam masyarakat.

Kebijakan hukum pidana tentang kompensasi berdasarkan pada konsep pemikiran bahwa kompensasi diposisikan sebagai suatu kewajiban negara dalam memberikan kompensasi kepada korban kejahatan sebagai wujud tanggungjawab negara atas korban tindak pidana. Perlindungan terhadap korban tindak pidana tidak hanya terhadap beberapa tindak pidana saja sebagaimana yang diatur dalam peraturan perundang-undangan seperti saat ini, tetapi juga perlu dipertimbangkan terhadap korban tindak pidana dalam perkara anak demi terwujudnya perlindungan yang seimbang antara pelaku tindak pidana anak dan korban tindak pidana dalam perkara anak. Pemberian perlindungan yang penuh kepada anak pelaku tindak pidana dengan tidak memproses perkaranya melalui proses peradilan harus diimbangi dengan pemberian perlindungan kepada korban dalam tindak pidana tersebut. Perlindungan kepada korban tindak pidana dalam perkara anak melalui kompensasi akan memberikan efek positif bagi terwujudnya perlindungan terhadap pelaku anak memalui keberhasilan kesepakatan diversi dan tidak memproses perkara anak tersebut ke dalam proses peradilan. Sebagai wujud tanggungjawab negara terhadap korban dalam proses penyelesaian perkara anak melalui diversi yang dilaksanakan melalui prinsip keadilan restoratif maka negara perlu segera membentuk suatu lembaga kompensasi yang berfungsi memberi ganti kerugian dan pembiayaan lainnya yang diperlukan korban kejahatan khususnya korban dalam perkara anak. Jaminan perlindungan korban oleh negara dalam sistem peradilan pidana anak akan mewujudkan Sistem Peradilan Pidana Anak terpadu, tidak saja terpadu antara masing-masing sub sistem dalam sistem peradilan pidana anak tetapi terpadu dengan kepentingan/perlindungan korban sehingga 
Perlindungan Korban Melalui Kompensasi Dalam Peradilan Pidana Anak

akan terwujud Victims-offender orientation in Child Criminal Justice System. Pendekatan keadilan restoratif melalui kompensasi akan lebih efektif dibandingkan hanya melalui pendekatan restitusi.

Untuk mewujudkan peradilan terpadu dalam peradilan anak tidak cukup melalui perubahan peraturan perundang-undangan saja, tetapi yang lebih penting adalah negara memiliki komitmen untuk membentuk lembaga kompensasi. Menurut Lembaga International for Criminal Justice Reform (ICJR) mengatakan negara masih abai terhadap perlindungan korban. Salah satu bentuk kepedulian negara dalam memberikan perlindungan terhadap korban tindak pidana adalah melalui pembentukan lembaga kompensasi yang bisa dimulai dengan pemberian kompensasi untuk korban tindak pidana dalam perkara anak. Pelaksanaan diversi melalui peradilan pidana masih memprioritaskan kepentingan anak sebagai pelaku, kepentingan korban dalam perkara anak belum sungguh-sungguh terlindungi.

Hal ini sejalan dengan fungsi negara adalah melindungi dan memberikan rasa aman bagi warganegaranya. Menurut Leslie Lipton hal ini merupakan fungsi negara yang tertua karena negara dibentuk oleh individu-individu, dan untuk mencapai tujuan perlindungan individu maka negara perlu dipertahankan. Abainya negara terhadap perlindungan korban kejahatan akan mengakibatkan hancurnya kepercayaan terhadap sistem penegakan hukum. Kepercayaan masyarakat terintegrasi dengan norma yang terbentuk melalui struktur hukum mulai dari kepolisian, kejaksaan, pengacara dan keadilan. Oleh sebab itu diperlukan perangkat hukum yang memberikan perlindungan pada korban tindak pidana dan perangkat hukum yang baik akan berfungsi sebagai media untuk membangun kembali kepercayaan masyarakat kepada sistem penegakan hukum. This trust is integrated with norms expressed in form of structured institutions such as police, attorney, and court, and so on. The crimes happening to the victims will mean the destruction of this system of trust.

Dalam kerangka tanggung jawab negara terhadap korban tindak pidana dapat diwujudkan dengan pemberian kompensasi. Kompensasi merupakan salah satu bentuk perwujudan tujuan negara hukum yaitu untuk menciptakan keadilan bagi seluruh warga negaranya, maka negara diharapkan mampu membuat kebijakan-kebijakan dalam mewujudkan keadilan bagi seluruh rakyat tersebut termasuk keadilan bagi korban. Jika dalam undang-undang ini penyelesaian tindak pidana anak diarahkan pada proses diversi yang bertujuan meminimalisir pidana penjara bagi pelaku anak maka disisi lain negara seharusnya bertanggungjawab dalam mewujudkan keadilan bagi korban, sehingga dengan demikian keadilan sebagai tujuan hukum akan terwujud dan pelaksanaan diversi melalui prinsip keadilan restoratif akan efektif.

Lembaga Kompensasi yang merupakan perwujudan komitmen negara terhadap perlindungan korban tentu saja memerlukan pendanaan yang besar, namun pendanaan lembaga ini sesungguhnya dapat berasal dari pelaku tindak pidana itu sendiri. Dalam beberapa tindak pidana cukup banyak 
perbuatan pidana yang selain diancam dengan pidana penjara tetapi juga diancam dengan pidana denda. Kebijakan hukum pidana di Indonesia melalui peraturan perundang-undangan perlu untuk mengefektifkan pembayaran sanksi pidana denda yang diterapkan pada pelaku tindak pidana, terutama untuk pelaku tindak pidana tertentu dengan nilai ekonomi yang besar seperti, peredaran narkotika, pencucian uang, tindak pidana korupsi, penggelapan pajak dsb. Melalui efektivitas pidana denda ini pembiayaan lembaga kompensasi sesungguhnya dapat berasal dari para pelaku tindak pidana itu sendiri. Negara hanya berfungsi sebagai pengumpul dan penyalur saja.

\section{PENUTUP}

Keberhasilan diversi yang masih rendah dipengaruhi oleh tidak tercapainya kesepakatan ganti kerugian pada korban dalam perkara anak. UUSPPA yang dengan tegas menyebutkan penyelesaian perkara anak melalui prinsip keadilan restoratif yang seharusnya mengutamakan perlindungan korban ternyata masih terfokus pada perlindungan anak sebagai pelaku semata. Perlindungan yang seimbang atas korban dan pelaku dalam perkara anak akan berdampak pada terwujudnya Peradilan Pidana Anak Terpadu (Integrated Juvenile Justice) untuk itu diperlukan revisi Undang-Undang Sistem Peradilan Pidana Anak dan Undang-Undang Perlindungan Saksi dan Korban sehingga fungsi sistem peradilan pidana anak sebagai pengendali kejahatan, perlindungan terhadap pelaku anak juga perlindungan korban akan berjalan serampak dan harmonis. Pendekatan keadilan restoratif melalui kompensasi akan lebih efektif dibandingkan hanya melalui pendekatan restitusi.

Sebagai saran perlu dibentuk lembaga kompensasi baik yang didanai pemerintah maupun swasta yang ditujukan untuk dukungan korban tindak pidana dalam perkara anak. Lembaga kompensasi ini berfungsi tidak hanya untuk ganti kerugian materiil tetapi juga dukungan pada korban berupa terapi, psiko patologi pasca trauma dan gangguan stress traumatis, termasuk pengobatan medis yang diperlukan. Perlindungan kepada korban tindak pidana dalam perkara anak melalui kompensasi, diharapkan akan memberikan efek positif bagi terwujudnya perlindungan terhadap pelaku anak melalui keberhasilan kesepakatan diversi. 
Perlindungan Korban Melalui Kompensasi Dalam Peradilan Pidana Anak

\section{DAFTAR PUSTAKA}

Buku

Eva Achjani Zulfa, Pergeseran Paradigma Pemidanaan, Lubuk Agung, Bandung: 2011.

Komisi Yudisial RI, Reformasi Peradilan dan Tanggung Jawab Negara, Jakarta: 2010.

Mahrus Ali, Melampaui Positivisme Hukum Negara, Aswaja Pressindo, Yogyakarta: 2013.

Peter Mahmud Marzuki, Penelitian Hukum, Kencana Prenada Media Group, Jakarta: 2011.

Rufinus Hotmaulana Hutahuruk, Penanggulangan Kejahatan Korporasi Melalui Pendekatan Restorative Suatu Terobosan Hukum, Sinar Grafika, Jakarta: 2013

The eleventh United Nation Congress on Crime Prevention and Criminal Justice, Bangkok Declaration Synergies and Responses: Strategic Alliances in Crime Prevention and Criminal Justice.

\section{Jurnal}

Eva Achjani Zulfa. "Keadilan Restoratif dan Revitalisasi Lembaga Adat”, Jurnal Kriminologi Indonesia, Volume 6 Nomor II. 2010.

Fachrie Bey dan Dian, "Pelaksanaan Fungsi dan Peran Lembaga Perlindungan Saksi dan Korban di Indonesia Sesuai Undang-Undang No. 13 Tahun 2006 tentang Perlindungan Saksi dan Korban”, Lex Jurnalika, Vol. 8, No.1, 2010.

Hafrida, "Restorative Justice In Juvenile Justice To Formulate Integrated Child Criminal Court", Jurnal Hukum dan Peradilan, Vol. 8, no. 3 (Nov), pp. 439 - 457, doi: 10.25216/JHP.8.3.2019.439-457, P. 445.

Hafrida, “Kebijakan Hukum Pidana Terhadap Pengguna Narkotika Sebagai Korban Bukan Pelaku Tindak Pidana: Studi Lapangan Daerah Jambi", Padjadjaran Jurnal Ilmu Hukum, Volume 3 Nomor 1 Tahun 2016. DOI: https://doi.org/10.22304/pjih.v3n1.a10.

Hafrida, H., Herlina, N., \& Adamy, Z, "The Protection of Women and Children as Victims of Human Trafficking in Jambi Province". Jambe Law Journal, 1(2), 207-230. https://doi.org/https://doi.org/10.22437/jlj.1.2.207-230.

Joe Hudson and Burt Galaway "Crime Victims and Public Social Policy," The Journal of Sociology \& Social Welfare, 1976, Vol. 3: Iss. 6, Article 3.

Kuat Puji Prayitno, "Restorative Justice Untuk Peradilan di Indonesia (Perspektif Yuridis Filosofis dalam Penegakan Hukum in Conreto), Jurnal Dinamika Hukum, Vol. 12 No. 3, September 2012.

Mahrus Ali dan Ari Wibowo, "Kompensasi dan Restitusi yang Berorientasi Pada Korban Tindak Pidana", Jurnal Yuridika, Vol. 33 No. 2 Mei Tahun 2018. 


\section{Peraturan Perundang-Undangan}

Undang-undang Nomor 11 Tahun 2012 tentang Sistem peradilan Pidana Anak

UU Nomor 30 Tahun 1999 tentang Arbitrase dan Alternatif Penyelesaian Sengketa.

Perma Nomor 4 Tahun 2014 tentang Pedoman Pelaksanaan Diversi dalam Sistem Peradilan Pidana Anak.

\section{Sumber Lain}

Harkristuti Harkrisnowo, Revisi Undang-Undang Pengadilan Anak Kedepankan Diversi. Hukum Online.com, 10 Maret 2010.

Huang Huang, "Unmet Needs and Service Satisfaction of Victim Support for the Direct and Indirect Victims of Serious Violence."

Kementerian Hukum dan Ham, Badan Pembinaan Hukum Nasional, Laporan Akhir tentang Kajian kompensasi bagi Pihak yang menderita kerugian dalam tindak pidana korupsi, 2013.

Geotimes, actual, critical, inspiring. "Indonesia Butuh Tambahan Lapas” Senin, 6 Juli 2015. Di akses, Minggu, 12 Pebruari 2017.

ICJR.or.id. diakses tanggal 4 Oktober 2019.

Oke News, Jumat 31 Maret 2017. 